\title{
Cutting Costs to Live Within Your Income ${ }^{1}$
}

Josephine Turner, Michael Gutter, and Nayda I. Torres ${ }^{2}$

Developing self-control of your spending is a basic step in cutting the cost of living. Some families instinctively seem to know how to get what they want, even on a limited income. But others need help in managing their finances to get what they need and want. Research shows that people worry more about money than any other family problem. If families communicate and everyone understands what the financial situation is, there will be greater cooperation.

\section{Planned Spending}

You and your family need to set goals and establish a plan for earning, saving, and spending money. Lack of planning may lead to serious difficulties. Planned spending is the first step for solving family money problems. Design your spending plan to suit your particular circumstances and your goals.

Here are the steps in making a personalized money plan:

1. Estimate your monthly take-home pay.

2. Write down an estimate of your basic expenses using your previous experience. Do not forget to include those expenses that occur quarterly or semi-annually, such as your insurance. If you are unable to recall the amounts, keep records of expenditures for two or three months. Your expenditures should reflect your goals. Almost every expense can be reduced. The main purpose of the spending plan is to give you direction in achieving your financial goals.

3. Test your spending plan. A simple spending record shows where your money actually goes. The trial test will show whether the plan is realistic. A good spending record will

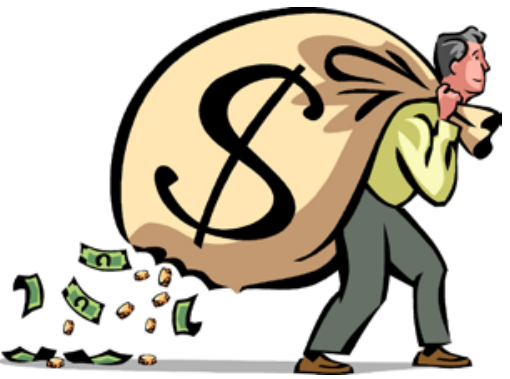
also locate money leaks, or spending that you never really intended.

\section{Tips for Reducing Spending}

You probably know of specific things you could do to reduce spending. The following suggestions may work for you.

1. This document is Fact Sheet FCS7009, one in a series of the Department of Family, Youth and Community Sciences, Florida Cooperative Extension Service, Institute of Food and Agricultural Sciences, University of Florida, Gainesville, FL 32611.First published: November 1987. Revised: February 2009. Please visit the EDIS Web site at http://edis.ifas.ufl.edu

2. Written by Nayda Torres, professor and Chair, Family and Consumer Economics. Revised by Josephine Turner, CFP, professor, Family and Consumer Economics, and Michael Gutter, assistant professor, Family Financial Management, Department of Family, Youth and Community Sciences, Institute of Food and Agricultural Sciences, University of Florida, Gainesville, FL 32611. 
Categorize your expenses as wants and needs. Needs include housing, basic utilities, childcare. Wants could include going out to eat, high fashion, newest electronics, etc. Wants we can space out over time.

Do not let your impulse determine major purchases. Postpone unplanned purchases 24 hours so you can rethink your plan.

Avoid shopping when you are down, depressed, tired, or hungry. If you have children, try to shop without them to reduce any sense of being rushed; feeling rushed may lead to impulse purchases.
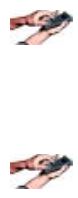

Reduce the number of trips you make to the stores. Wait until there are things you need.

Try to plan purchases around seasonal sales throughout the year.

Pre-shop to stop spending leaks. Decide what you want and why you want it before you go shopping. Make it a habit to compare prices and values.

If at all possible, try out or try on the item before you buy it. This practice will provide you with the opportunity to determine if the item will meet your needs.

Compare the cost per unit of items available in different sizes. It is not always cheaper to buy in bulk.

Save on food by planning meals with abundant seasonal items and supermarket specials. Take a carefully prepared list to the grocery store and stick closely to it. Utilize point-of-sale information for comparing product quality and price.

Save on clothes by planning your wardrobe. Check for fit, and buy only clothes that fit comfortably. Coordinate your clothing and accessory items. Examine care labels for fiber content and cleaning instructions. By taking proper care of your clothes, you will make them last longer and save money on replacements.

Save on transportation by selecting an automobile that adequately meets your needs, but does so without extremely high costs. A fuel-efficient automobile will yield substantial savings over time. Planning trips in logical sequences instead of doubling back to places you have already been also saves fuel.

If you have debts, accelerate repayment. There is little reason to retain savings that earn 3\% interest while you still owe installment debts and loans that carry true interest rates of 12 to 22 percent.

For your banking services, select an institution with the lowest service charges on your accounts. Some banks do not charge anything as long as you keep your checking account above a certain minimum amount.

Buy property insurance at a reasonable cost. In general, you save by combining several types of coverage in one policy. A homeowner's package policy costs less than separate fire, theft, and liability insurance policies.

When buying insurance, avoid buying on a weekly or installment basis. This costs you much more than payments made every six months or annually. 
House repairs can be costly. Get competitive bids from reputable firms before the work is started.

Maintain your furnace or airconditioner by remembering to change or clean the air return filter regularly. Not only is it less efficient to have the fan pull air through a dirty filter, but also a clogged filter can burn out the motor and cost you a repair bill.

Take steps to conserve heat, cool air, and hot water. Use weather stripping, caulking, and insulation to reduce utility bills.

Water leaks are not only annoying, but also expensive. Water-use charges vary from one locality to the next. A series of seemingly minor leaks can run your water usage up several thousand gallons a year.
Water your lawn, not the pavement. A carelessly-placed or over-powerful sprinkler can send many dollars worth of water washing down the sidewalk and into the gutter each year.

When buying a household appliance, remember that the bottom-of-the-line model will perform its intended function without the frills of the more expensive top-of-the-line model.

Compare the included warranty coverage of the appliances you are considering in your purchase decision as many extended warranties/service contracts are overpriced. A way to save on the high cost of repairs is to avoid them.

7 Additional tips can be found in the Managing in Tough Times publication from UF/IFAS Extension. It is available free at:

http://solutionsforyourlife.ufl.edu/families_ and_consumers/money_matters/managing in_tough_times.html. 